\title{
KEFAHAMAN MAHASISWA MUSLIM LEMBAH KLANG TENTANG KONSEP HAK KEBEBASAN BERAGAMA DI MALAYSIA
}

\author{
Kamal Azmi Abd Rahman, Norsaleha Mohd Salleh \& Nazneen Ismail
}

Faculty of Islamic Civilization Studies, International Islamic University College Selangor (KUIS), 43000, Kajang, Malaysia.

Correspondence Author: Kamal Azmi Abd Rahman. Department of Dakwah and Usuluddin, Faculty of Islamic Civilization Studies, International Islamic University College Selangor (KUIS), Bandar Seri Putra, 43000 Kajang, Selangor. E-mail: kamalazmi@kuis.edu.my

\begin{abstract}
ABSTRAK
Konsep hak kebebasan beragama yang difahami berdasarkan kepada prinsip Islam dan Perlembagaan Negara tidak bersifat mutlak dan terbatas. Rentetan itu, terbentuknya beberapa kumpulan Non-Governmental Organization (NGO) baru seperti IFC (Islam Interfaith Commision) atau nama sebenarnya IRC (Inter Religious Centre), Kumpulan Artikel 11 dan COMANGO (Coalition of Malaysian NGOs in the UPR Process) atau Gabungan Pertubuhan Bukan Kerajaan Malaysia yang menuntut agar hak kebebasan beragama difahami secara terbuka sepertimana yang termaktub di dalam Universal Declaration of Human Rights (UDHR), 1948. Antara isu yang seringkali dikaitkan dengan hak kebebasan beragama di Malaysia ialah isu murtad atau menukar agama. Oleh yang demikian, kajian ini dijalankan untuk mengenal pasti tahap kefahaman mahasiswa Muslim di Lembah Klang tentang konsep hak kebebasan beragama di Malaysia. Kajian adalah berbentuk kuantitatif dan tinjauan yang akan menggunakan set soal selidik sebagai instrumen untuk mendapatkan data. Sampel seramai 404 orang responden telah dipilih dengan menggunakan kaedah persampelan bertujuan (purposive sampling) dalam kalangan mahasiswa Muslim yang sedang mengikuti pengajian di institusi pengajian tinggi awam dan swasta di sekitar Lembah Klang. Kajian mendapati tahap kefahaman mahasiswa Muslim di Lembah Klang tentang konsep hak kebebasan beragama adalah tinggi dengan skor $\min 4.32$ (sp = 0.82). Dapatan ini menunjukkan bahawa walaupun terdapat isu tentang hak kebebasan beragama serta pelbagai tuntutan yang telah dibuat oleh beberapa NGO yang mempromosikan konsep hak kebebasan yang baru dan terbuka, mahasiswa Muslim masih lagi mengekalkan konsep kefahaman hak kebebasan beragama yang menepati Perlembagaan Negara dan prinsip Islam.
\end{abstract}

Kata kunci: Kebebasan; Agama; Mahasiswa; Muslim; Lembah Klang; Murtad 


\title{
(THE UNDERSTANDING OF KLANG VALLEY MUSLIM STUDENTS ON CONCEPT OF RELIGIOUS FREEDOM IN MALAYSIA)
}

\begin{abstract}
The concept of religious freedom based on the Islamic perspective and the National Constitution is not absolute and limited. Because of that, several groups of NonGovernmental organizations (NGO) emerged, such as Islam Interfaith Commission (IFC) or Inter-Religious Centre (IRC), Group of Article 11, and the Coalition of Malaysian NGOs in the UPR Process (COMANGO) whereby calling for an absolute understanding of religious freedom as it is set forth in the Universal Declaration of Human Rights (UDHR), 1948. Among the issues repeatedly associated with religious freedom in Malaysia is the issue of apostasy. Therefore, this research is conducted to identify the level of Muslim students' understanding of the concept of religious freedom in Malaysia. This research is qualitative and exploratory based which used a set of questionnaires as an instrument to collect data. By using the purposive sampling method, a total of 404 respondents were selected among Muslim students at government or private higher learning institutions in Klang Valley. The research found that the level of Muslim students understanding of the concept of religious freedom at Klang Valley is high with a min score of $4.32(s d=0.82)$. This finding shows that although there are several issues concerning religious freedom and a variety of demands from NGOs who are promoting the new and liberal concept of religious freedom, Muslim students still continue to understand the concept as it was institutionalized in the National Constitution and Islamic principle.
\end{abstract}

Kata kunci: Freedom; Religion; Students; Muslim; Klang Valley; Apostasy

Received: August 2, 2017

Accepted: October 19, 2017

Online Published: June 30, 2018

\section{Pengenalan}

Hak kebebasan beragama merupakan salah satu daripada perkara yang terkandung di dalam Deklarasi Hak Asasi Manusia (HAM), PBB pada 1 Januari 1942. Ia adalah hak individu untuk mengikut kepercayaan agama sebagaimana yang dipilih olehnya, hak untuk menyatakan pegangan agama secara terbuka tanpa ketakutan atau halangan yang menyebabkan ia dikenakan sesuatu tindakan serta hak untuk mengisytiharkan kepercayaan melalui pemujaan dan amalan, ajaran dan sebaran. Merujuk kepada Perkara 18, Deklarasi Hak Asasi Manusia Sejagat atau Universal Declaration of Human Rights (UDHR) 1948, hak kebebasan beragama adalah:

Setiap orang adalah berhak untuk mendapat kebebasan berfikir, perasaan hati dan agama; hak ini termasuklah kebebasan menukar agama atau kepercayaannya, dan kebebasan, samada secara bersendirian atau secara bersama-sama dengan orang-orang lain dan secara terbuka atau bersendiri, menganuti agama atau kepercayaannya melalui pengajaran, amalan, pemujaan dan kepatuhan. 
Menurut perspektif Islam, setiap individu mempunyai hak kebebasan beragama, mengamalkan dan beribadat mengikut agama yang dianuti individu tersebut. Jesteru itu, setiap manusia juga diberi kebebasan untuk memilih mana-mana agama untuk dianuti. Seperti firman Allah SWT dalam surah al-Kahf ayat 29:

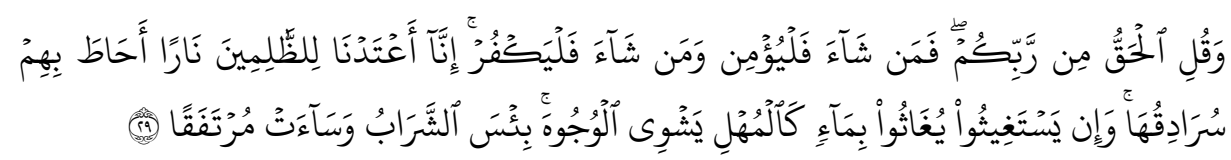

Maksudnya:

Dan katakanlah (wahai Muhammad): Kebenaran itu ialah yang datang dari Tuhan kamu, maka sesiapa yang mahu beriman, hendaklah dia beriman dan sesiapa yang mahu kufur ingkar, biarlah dia mengingkarinya. Kerana Kami telah menyediakan bagi orang-orang yang berlaku zalim itu api Neraka, yang meliputi mereka laksana khemah; dan jika mereka meminta pertolongan kerana dahaga, mereka diberi pertolongan dengan air yang seperti tembaga cair yang membakar muka; amatlah buruknya minuman itu dan amatlah buruknya Neraka sebagai tempat bersenangsenang.

Manusia dilahirkan ke dunia dalam keadaan bersih (fitrah) dan bebas daripada perhambaan, dosa dan kasta. Semua hal tersebut dijamin dalam Islam. Walau bagaimanapun, kebebasan yang diperakukan tidak mutlak kerana ia bertentangan dengan prinsip asas agama dan worldview Islam. Dalam konteks ini, Islam melarang penganutnya meninggalkan agama atau murtad kerana bercanggah dengan Akidah dan Syariah. Apatah lagi, pemeliharaan agama adalah aspek penting bagi kemaslahatan manusia berdasarkan kepada ḍaūriyyah al-khamsah yang menunjangi maqāṣid alsharicah (Helwa 2014).

Jaminan hak kebebasan beragama juga terkandung di dalam perlembagaan, Perkara 11(1), Perlembagaan Persekutuan yang memperuntukkan bahawa: "Tiap-tiap orang adalah berhak menganuti dan mengamalkan agamanya." Selain itu, perlembagaan juga memperuntukan Islam sebagai agama persekutuan. Oleh yang demikian, sebagai orang Islam di Malaysia, mereka bukan sekadar tertakluk kepada prinsip kebebasan beragama dalam Islam, bahkan juga kepada Perlembagaan Persekutuan. Namun begitu, perlembagaan tetap tidak menafikan hak kebebasan beragama penganut agama lain dari aspek kepercayaan dan pengamalannya.

Hal tersebut menepati prinsip Islam yang tidak memaksa mana-mana individu atau golongan bukan muslim untuk memeluk agama Islam. Ini seperti mana yang terkandung di dalam surah al-Baqarah ayat 256:

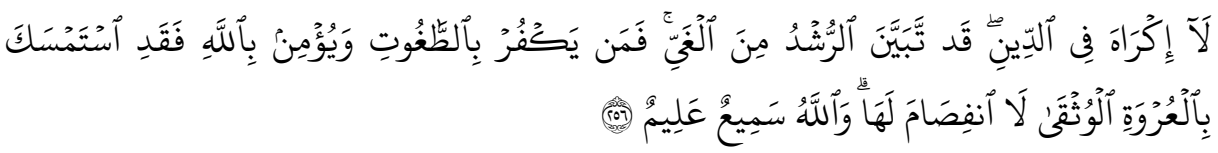

Maksudnya:

Tidak ada paksaan dalam agama (Islam), kerana sesungguhnya telah nyata kebenaran (Islam) dari kesesatan (kufur). Oleh itu, sesiapa yang tidak percayakan Taghut, dan ia pula beriman kepada Allah, maka sesungguhnya ia telah berpegang 
Published by Faculty of Islamic Civilization Studies, KUIS

kepada simpulan (tali agama) yang teguh yang tidak akan putus. Dan (ingatlah), Allah Maha Mendengar lagi Maha Mengetahui.

Selain itu, Piagam Madinah yang telah dimeterai oleh Rasulullah SAW dengan warga Madinah juga menjelaskan tentang ‘tiada paksaan dalam Islam' apabila Baginda SAW membenarkan masyarakat bukan Islam terutamanya golongan Yahudi tinggal di Madinah dan kekal menganut agama mereka. Ini sepertimana yang terkandung dalam Fasal 25, Piagam Madinah:

\begin{abstract}
Kaum Yahudi dari Bani 'Awf adalah umat dengan mukminin. Bagi kaum Yahudi agama mereka, dan bagi kaum muslimin agama mereka. Juga (kebebasan ini berlaku) bagi sekutu-sekutu dan diri mereka sendiri, kecuali bagi yang zalim dan jahat. Hal demikian akan merosak diri dan keluarganya.
\end{abstract}

\title{
2. Hak Kebebasan Beragama Di Malaysia
}

Berdasarkan kepada sejarah, penggubalan hak asasi manusia sudah bermula sejak era Magna Carta, 1215. Walaupun begitu, isu tentang kebebasan dan hak asasi manusia menjadi satu isu yang lebih penting dalam masyarakat Di Barat selepas Revolusi Perancis dengan terbentuknya sistem negara-bangsa (nation state). Revolusi ini berlatarbelakangkan peperangan antara agama, diskriminasi, hak kebebasan (liberte), kesamarataan (egalite) dan persaudaraan (fraternite) yang merujuk kepada falsafah bahawa manusia lahir dalam keadaan bebas dan sama rata bagi hak-haknya. Oleh itu, idea awal tentang hak asasi manusia (HAM) telah mula diperkenalkan di Barat sebagai manifestasi kemerdekaan dan kebebasan daripada semua nilai-nilai tradisi yang mengongkong terutamanya nilai tadisi yang diwarisi daripada ajaran agama. Idea-idea yang dikembangkan di dalam HAM adalah berdasarkan prinsip humanismesekularisme iaitu tiada nilai tradisi, nilai kudus, agama dan spiritual. Setelah melalui proses yang panjang, naskhah hak asasi manusia akhirnya terbentuk pada tahun 1948 di PBB dengan nama Universal Declaration of Human Rights (UDHR). Oleh yang demikian, gagasan HAM adalah bersumberkan kepada natural rights theory (Retno Kusniati 201, Andrey Sujatmoko 2009 \& Md Akhir 1985). Empat perkara utama dalam UDHR ini adalah kebebasan daripada ketakutan, kebebasan terhadap kemahuan, kebebasan bersuara dan kebebasan kepercayaan. Hal-hal yang berkaitan dengan hak kebebasan beragama individu terkandung di dalam perenggan 18, UDHR 1948.

Hak kebebasan beragama menjadi perkara penting yang harus difahami oleh setiap manusia moden. Menurut Ridwan Arif (2010) isu kebebasan beragama menjadi signifikan terutamanya sejak awal kurun ke-20 apabila kumpulan agama minoriti muncul di negara-negara maju Eropah, Amerika Syarikat, Australia dan negara-negara lain. Oleh kerana faktor perpindahan penduduk, revolusi komunikasi dan globalisasi, isu permasalahan kebebasan beragama merupakan masalah sejagat bukan masalah khas bagi sesebuah negara. Hak kebebasan beragama adalah meliputi hak untuk beragama, menukar agama, hak untuk beribadah sesuai dengan keyakinan dan hak untuk mengajarkan agamanya. Tanpa mengira agama dan latar belakang, hak-hak tersebut dijamin kepada setiap individu atau kumpulan sepertimana yang terkandung di dalam UDHR 1948.

Walau bagaimanapun, pemahaman tentang hak kebebasan beragama yang terkandung di dalam deklarasi tersebut berbeza dengan hak kebebasan beragama 
menurut perspektif Islam kerana pembinaannya didasari oleh konsep negara sekular (Helwa et. al. 2013 \& Faridah et. al. 2014). Ia mempromosikan maksud kebebasan yang mutlak (Frans Sayogie 2013). Sebaliknya, hak kebebasan beragama menurut Islam adalah kebebasan yang tidak mutlak dan terma kebebasan tersebut juga berbeza antara Muslim dengan bukan Muslim. Kebebasan agama yang dijamin oleh Islam terletak pada konsep 'tiada paksaan' dan penganut agama lain adalah bebas untuk menjalankan kegiatan keagamaan mereka. Ini seperti yang terkandung di dalam perkara 25, Piagam Madinah iaitu penganut agama lain tidak dipaksa untuk memeluk agama Islam dan pada masa yang sama mereka juga tidak dihalang untuk menjalankan amalan keagamaan mereka. Mereka juga berhak untuk menjalankan upacara agama masing-masing dalam kehidupan seharian, walaupun di tempat yang dikelilingi oleh orang Islam selagi mana mereka tidak memberi ancaman atau hasutan kepada orangorang Islam (Hidayat 2012). Buku yang berjudul Islam dan Kepercayaan Lain oleh Ismail Raji al-Faruqi (2009) menyatakan bahawa terdapat terma khusus bagi hak kebebasan beragama non-muslim iaitu Pax Islamica. Pax Islamica bermaksud jaminan kebebasan terhadap golongan bukan Islam untuk meyakini tentang kebenaran Islam. Mereka yang telah menerima seruan dakwah diberikan hak memilih dan mempertimbangkan kebaikan dan keburukan terhadap seruan tersebut.

Dalam konteks Malaysia, Kebebasan beragama merupakan hak kebebasan asasi yang dijamin oleh Perlembagaan Persekutuan Malaysia kepada setiap warganegaranya. Ini berdasarkan kepada Perkara 11(1), Perlembagaan Persekutuan yang telah memperuntukkan "Tiap-tiap orang adalah berhak menganuti dan mengamalkan agamanya." Walaupun perlembagaan menjamin hak kebebasan beragama setiap individu, hak tersebut juga adalah tidak mutlak sesuai dengan prinsip Islam terutama sekali dalam hal-hal yang berkaitan dengan penukaran agama atau keluar dari Islam. Ini bermaksud hak kebebasan untuk menukar agama tidak diberikan kepada penganut agama Islam sesuai dengan peraturan dan prinsip agama Islam sendiri. Hal yang demikian tidak melanggar prinsip kebebasan kerana sesebuah negara dibolehkan untuk membatasi hak tertentu dengan dasar atau klausa pembatasan (Frans Sayogie 2013). Walau bagaimanapun, pembatasan tersebut telah menimbulkan polemik dan kekeliruan dalam memahami konsep hak kebebasan beragama di Malaysia terutamanya hal-hal yang melibatkan hak Islam dan Muslim serta hak golongan bukan Islam dan agama mereka. Hal ini juga berlanjutan sehingga membentuk persepsi masyarakat bukan Islam terhadap perubahan atau proses Islamisasi yang berlaku di Malaysia bertentangan dengan Perlembagaan Negara yang sepatutnya menjamin hak kebebasan beragama setiap individu (Abdul Rahman 2009).

Antara isu-isu yang berkaitan dengan hak kebebasan beragama di Malaysia adalah hak orang Islam untuk menukar agamanya, keluar dari Islam ataupun murtad. Antara kes murtad yang pernah difailkan di mahkamah ialah kes Lina Joy lawan Majlis Agama Islam Wilayah Persekutuan. Pertembungan antara konsep hak kebebasan beragama yang bebas seperti yang difahami melalui UDHR 1948 dengan hak kebebasan beragama yang difahami melalui perspektif Islam dan perlembagaan menimbulkan pelbagai interpretasi tentang maksud hak kebebasan agama yang sebenar. Antara yang dipersoalkan adalah tentang hak kebebasan beragama yang diperuntukan oleh di dalam Perkara 11(1), Perlembagaan Persekutuan adalah terbatas terutamanya dalam hal-hal yang berkaitan dengan ajaran Islam seperti isu murtad. Oleh yang demikian, terdapat pihak yang menyatakan bahawa Islam telah menyanggahi maksud hak kebebasan individu untuk memilih agama mereka sendiri (Helwa et. al. 2014). Rentetan daripada polemik tersebut, telah lahir beberapa pertubuhan NGO di Malaysia antaranya, Islam Interfaith Commision (IFC) atau nama 
Published by Faculty of Islamic Civilization Studies, KUIS

sebenarnya Inter Religious Centre (IRC), yang mana turut dikenali sebagai Majlis Suruhanjaya Antara Agama-Agama. Agenda utama penubuhannya adalah meletakkan semua agama dalam kedudukan yang sama sehingga setiap orang bebas untuk menentukan status agama masing-masing serta memastikan tidak ada halangan bagi seorang Muslim untuk murtad (Mazlan et. al. 2012, Mohamed Azam 2015). Pertubuhan IRC ini ditaja oleh MCCBCHS (Malaysian Consultative Council of Buddhism, Christianity, Hinduism and Sikhism) melalui memorandum yang telah dihantar ke Majlis Peguam Malaysia (Bar Council) pada 21 Ogos 2001. Berdasarkan memorandum yang dinyatakan oleh IRC, jelas membuktikan bahawa setiap individu berhak menuntut hak kebebasan beragama termasuk agama Islam. Antara kandungan memorandum tersebut adalah seperti berikut (Mazlan et. al. 2012; Mohamed Azam 2015):

i. Seseorang atau pasangan suami isteri yang menukar agamanya dengan memeluk Islam tidak patut diberikan hak penjagaan anak;

ii. Orang bukan Islam yang mempunyai hubungan kekeluargaan dengan seorang yang memeluk Islam hendaklah diberikan hak menuntut harta pusakanya selepas kematiannya;

iii. Kerajaan hendaklah menyediakan dana yang mencukupi untuk membina dan menyelenggara rumah-rumah ibadat orang bukan Islam sebagaimana kerajaan menyediakan dana yang sama untuk masjid. Kerajaan juga perlu membenarkan pembinaan rumah-rumah ibadat orang bukan Islam tanpa perlu adanya peraturanperaturan tertentu;

iv. Orang bukan Islam hendaklah dibenarkan dan tidak boleh dihalang daripada menggunakan perkataan-perkataan suci Islam dalam percakapan dan sebagainya;

v. Bible dalam Bahasa Malaysia dan Bahasa Indonesia sepatutnya dibenarkan untuk diedarkan kepada umum secara terbuka;

vi. Pelajaran agama bukan Islam untuk penganut agama itu hendaklah diajar di semua sekolah;

vii. Program berunsur Islam dalam bahasa ibunda sesuatu kaum hendaklah ditiadakan;

viii. $\quad$ Orang Islam yang membayar zakat tidak sepatutnya dikecualikan daripada membayar cukai pendapatan dan wang sepatutnya digunakan juga untuk keperluan orang bukan Islam;

ix. Sepatutnya Islam tidak disebut sebagai pilihan pertama masyarakat Malaysia seperti dalam soal pakaian menutup aurat kepada pelajar sekolah; dan

x. Orang bukan Islam tidak perlu menganut Islam tidak perlu menganut Islam sekiranya ingin berkahwin dengan orang Islam. Orang Islam dibenarkan keluar daripada Islam (murtad) sekiranya ingin berkahwin dengan orang bukan Islam tanpa dikenakan apa-apa tindakan undang-undang. 
Selain itu, Kumpulan Artikel 11 juga membawa agenda yang sama untuk menegakkan keluhuran perlembagaan dan menggalakkan kebebasan beragama yang bersifat mutlak. Pertubuhan COMANGO (Coalition of Malaysian NGOs in the UPR Process) atau Gabungan Pertubuhan Bukan Kerajaan Malaysia turut sama aktif menuntut pelbagai syor yang berkaitan dengan hak asasi manusia. Berdasarkan kepada tuntutan tersebut, dalam perenggan 10 iaitu kebebasan beragama, ekspresi, perhubungan dan pehimpunan aman dan menyertai kehidupan awam dan berpolitik. (Freedom of Religion or belief, expression, association and peaceful assembly, and right to participate in public and political life). Dalam perenggan ini terdapat 23 isi laporan/sub isi laporan dan 11 syor. Antaranya ialah 10.1.1 The Herald dihalang menggunakan kalimah Allah, 10.1.6 Tiada kebebasan agama bagi orang Islam, ajaran Syiah dilebel sesat, 10.1.9 Terjemahan Allah, Liberty \& Love dilarang oleh KDN dan 10.1.11 Hak bapa yang mengislamkan anak-anak di bawah umur telah dipertikaikan. Selain itu, kumpulan Sisters in Islam juga mempersoalkan larangan murtad kerana Muslim menuntut kebebasan dan mahu menarik lebih ramai orang bukan Islam untuk memasuki Isalm tetapi dalam masa yang sama tidak membenarkan penganutnya keluar dari agama tersebut (Rafidah 2014).

Senario perjuangan hak kebebasan beragama negara serantau seperti di Indonesia juga dilihat begitu terbuka. Menurut Ridwan Arif (2010) dan Siti Musdah Mulia (2006) pula merumuskan tentang hak kebebasan beragama dalam konteks kehidupan plural masyarakat Indonesia bedasarkan kepada interpretasi yang dibuat oleh Jaringan Islam Liberal (JIL). Islam seharusnya menjamin kewujudan kebebasan beragama dan ianya merupakan hak manusia yang paling asas. Kebebasan beragama dapat menumbuhkan rasa saling menghormati antara warga negara yang berbeza agama dan bangsa. Oleh itu, ia membawa kepada timbulnya sikap toleransi dan perasaan cinta antara sesama mereka. Kebebasan beragama menurut JIL merangkumi beberapa perkara, iaitu:

i. Kebebasan memilih dan menganuti agama;

ii. Kebebasan untuk tidak beragama;

iii. Kebebasan bertukar agama;

iv. Kebebasan menyebarkan agama;

v. Kebebasan melaksanakan agama;

vi. Kebebasan melakukan perkahwinan berbeza agama;

vii. Kebebasan mempelajari sebarang ajaran agama;

viii. Memberi kebebasan munculnya sesuatu agama atau aliran keagamaan baru; dan

ix. Sikap dan tindakan yang adil daripada Kerajaan kepada semua penganut agama dan kepercayaan.

Kerterbukaan hak kebebasan beragama dapat dilihat melalui saranan untuk membenarkan seseorang bertukar agama (murtad), perkahwinan beza agama dan aliran-aliran keagamaan baru yang mana jelas bertentangan dengan Islam (Ridwan Arif, 2010).

Walaupun Perlembagaan Persekutuan telah menggariskan tafsiran hak kebebasan beragama yang jelas, namun terdapat sesetangah pihak yang cuba mentafsirkannya semula agar bersesuaian dengan tafsiran umum dan bebas seperti yang terkandung di dalam UDHR 1948. Kebebasan beragama yang difaham secara mengikat bagi kumpulan ini merupakan bentuk extrimisme atau fundamentalisme. Dalam konteks Malaysia, hak kebebasan beragama adalah bersyarat iaitu terikat dengan keselamatan awam, kesihatan, moral, keteraturan dan kestabilan negara. Oleh 
Published by Faculty of Islamic Civilization Studies, KUIS

yang demikian, dalam isu menukar agama atau murtad, negara bertanggungjawab untuk mempertahankan agama Islam sebagai agama persekutuan dan perbuatan murtad merupakan satu penentangan terhadap Islam (Helwa 2013).

\section{Metodologi}

Kajian yang dijalankan adalah kajian penyelidikan kuantitatif secara tinjauan dengan menggunakan instrumen borang soal selidik. Borang soal selidik yang digunakan mengandungi dua bahagian seperti berikut: Bahagian A: Demografi responden (jantina, umur, tahap pendidikan, Institusi Pengajian, latar belakang pendidikan, fakulti dan lain-lain), manakala Bahagian B: Tahap pengetahuan mengenai hak kebebasan beragama. Bagi mengukur tahap kefahaman mahasiswa Muslim mengenai konsep hak kebebasan beragama, kajian menggunakan Skala Likert bermula daripada skala 1 (sangat tidak setuju) sehingga 5 (sangat setuju) bagi setiap item.

Kajian ini menggunakan kaedah pensampelan nonprobability dengan menggunakan teknik persampelan bertujuan atau purposive sampling. Responden adalah terdiri daripada mahasiswa Muslim yang sedang mengikuti pengajian di institusi pengajian tinggi yang terpilih. Penentuan saiz sampel adalah berdasarkan kepada jadual Krejcie dan Morgan (1970). Berdasar kepada Ringkasan Eksekutif Pelan Pembangunan Pendidikan Malaysia 2015-2025 (Pendidikan Tinggi), jumlah mahasiswa IPTA dan IPTA pada tahun 2012 adalah 1 juta orang. Oleh yang demikian, seramai 404 orang responden (minimum 384 orang) telah dipilih dalam kalangan mahasiswa Muslim yang sedang menuntut di pusat pengajian tinggi sama ada Institusi Pengajian Tinggi Awam (IPTA) atau Institut Pengajian Tinggi Swasta (IPTS) di Lembah Klang. Data-data yang dikumpul dianalisis dan akan diberikan interpretasi mengikut nilai min seperti yang terdapat pada Jadual 1 .

Jadual 1. Interpretasi skor min

\begin{tabular}{ll}
\hline Nilai Min & Tahap \\
\hline $1.00-2.33$ & Rendah \\
$2.34-3.67$ & Sederhana \\
$3.68-5.00$ & Tinggi \\
\hline
\end{tabular}

Sumber: Landell, 1977.

\section{Dapatan Kajian}

\subsection{Demografi Responden}

Bahagian demografi responden mempunyai 10 item iaitu institusi pengajian, jantina, umur, asal, peringkat pengajian, bidang pengajian, latar belakang pendidikan sekolah menengah, pekerjaan, penglibatan organisasi dan bahan bacaan portal online yang digemari. Berikut adalah data-data yang diperolehi daripada demografi atau latar belakang responden:

1. Institusi Pengajian

Jadual 2. Institusi pengajian responden

\begin{tabular}{llllll}
\hline Maklumat & Kekerapan & Peratus & $\begin{array}{l}\text { Kekerapan } \\
\text { Keseluruhan }\end{array}$ & $\begin{array}{l}\text { Peratus } \\
\text { Keseluruhan }\end{array}$ \\
\hline IPTA & UIAM & 49 & 12.1 & 240 & 59.4 \\
\hline
\end{tabular}




\begin{tabular}{|c|c|c|c|c|c|}
\hline \multicolumn{4}{|c|}{ ISSN 0128-116X } & & VOL. 3, NO. 1, JUNE 2018 \\
\hline \multirow{13}{*}{ IPTS } & UKM & 55 & 13.5 & \multirow{13}{*}{164} & \multirow{13}{*}{40.6} \\
\hline & UM & 40 & 9.9 & & \\
\hline & UPM & 51 & 12.6 & & \\
\hline & UiTM & 45 & 11.1 & & \\
\hline & KUIS & 42 & 10.3 & & \\
\hline & Cyberjaya & 14 & 3.4 & & \\
\hline & MSU & 18 & 4.4 & & \\
\hline & OUM & 9 & 2.2 & & \\
\hline & Unikl & 17 & 4.2 & & \\
\hline & Unisel & 30 & 7.4 & & \\
\hline & КРТM & 20 & 4.9 & & \\
\hline & IOC & 10 & 2.5 & & \\
\hline & Uniten & 4 & 1 & & \\
\hline
\end{tabular}

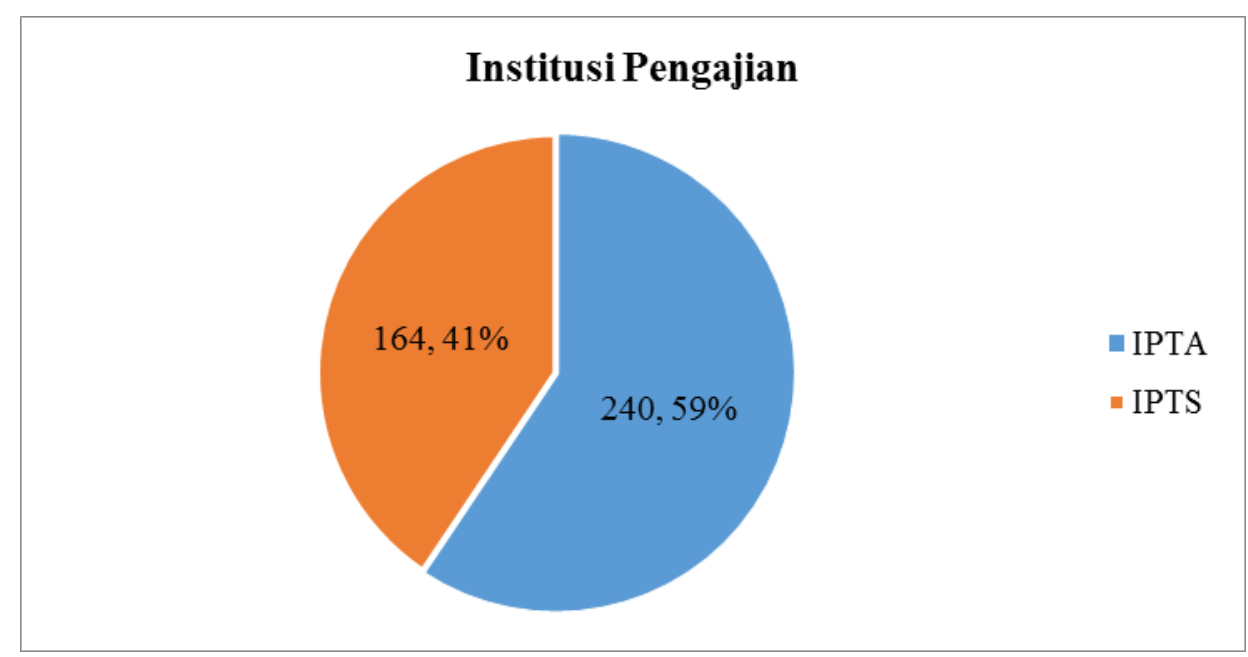

Rajah 1. Carta bar institusi pengajian 
Published by Faculty of Islamic Civilization Studies, KUIS

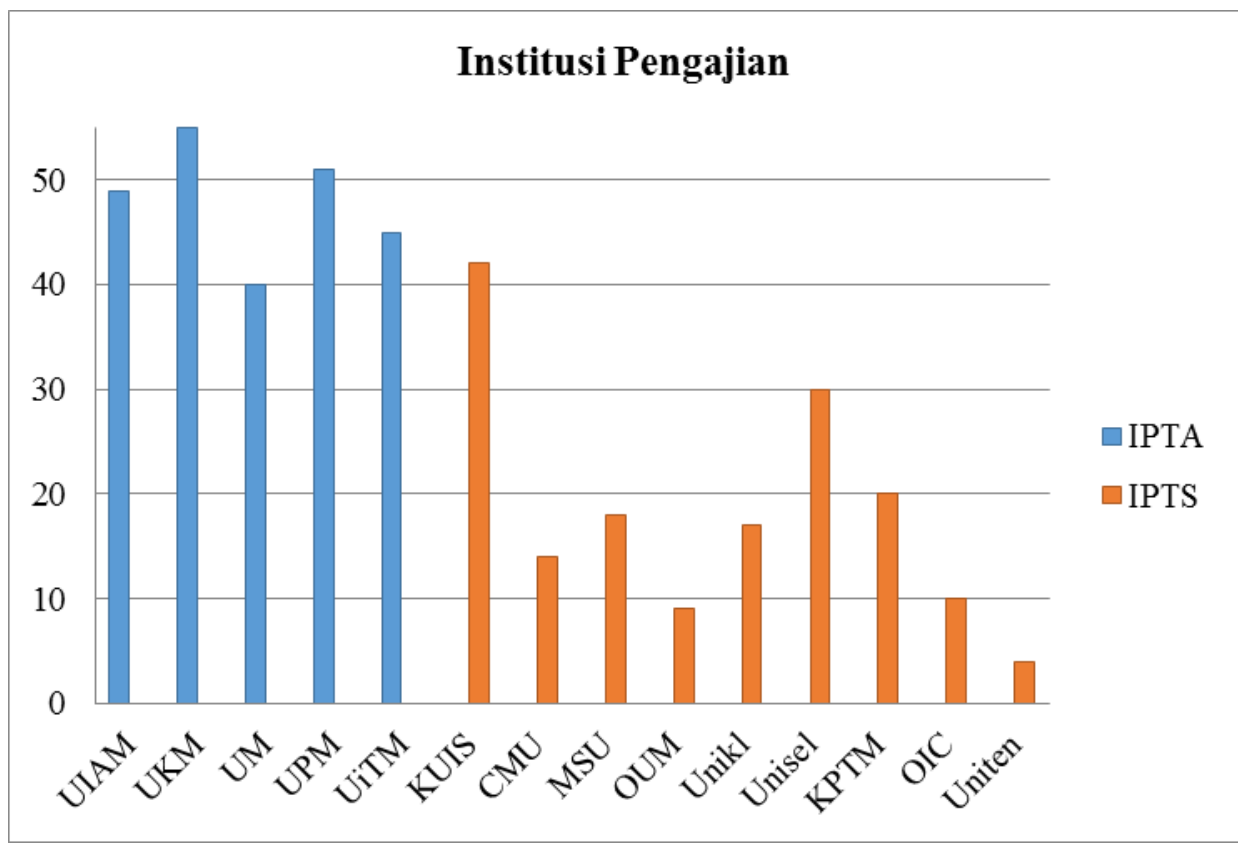

Rajah 2. Graf institusi pengajian

2. Jantina

Jadual 3. Jantina responden

\begin{tabular}{lll}
\hline Maklumat & Kekerapan & Peratus \\
\hline Lelaki & 186 & 46 \\
Perempuan & 218 & 54 \\
\hline
\end{tabular}

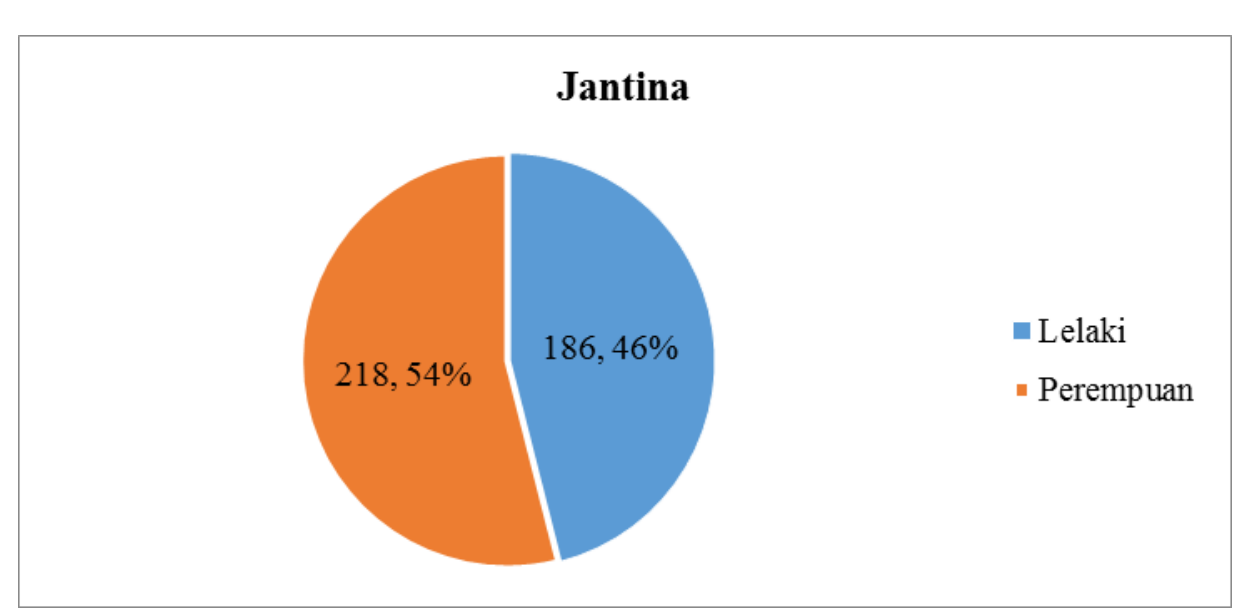

Rajah 3. Carta bar jantina responden 
3. Umur

Jadual 4. Umur responden

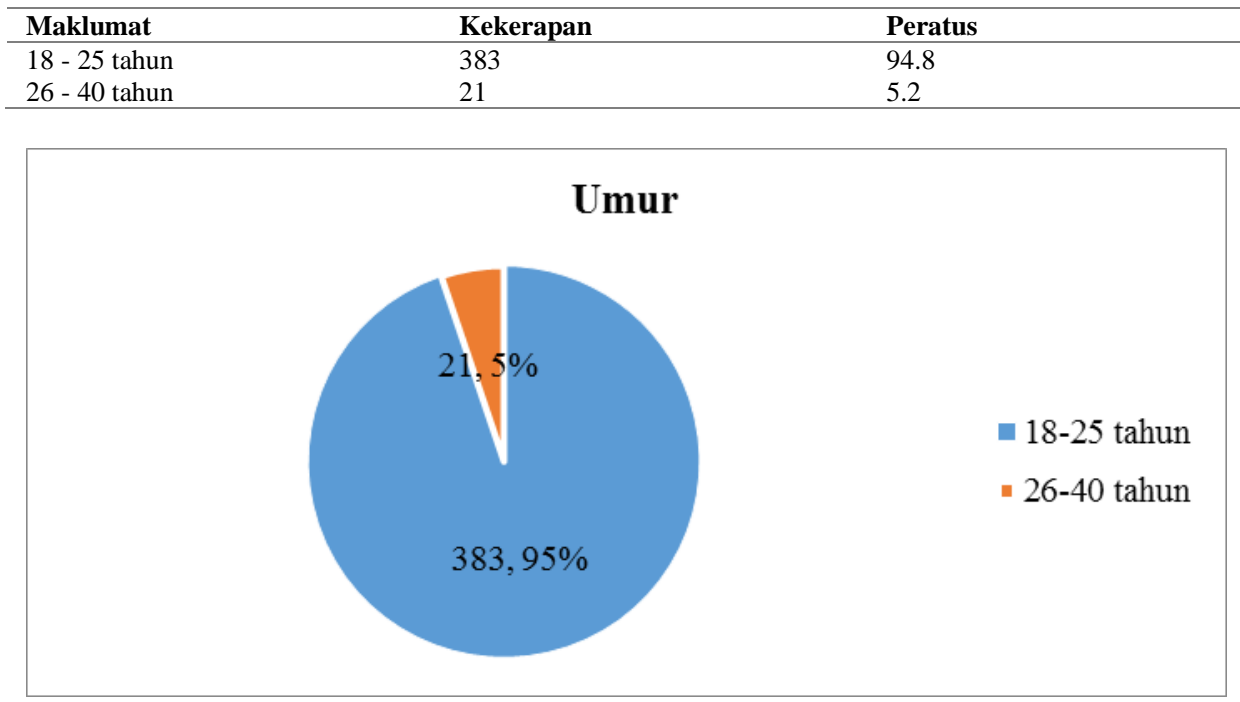

Rajah 4.Carta bar umur responden

4. Asal

Jadual 5. Asal responden

\begin{tabular}{lll}
\hline Maklumat & Kekerapan & Peratus \\
\hline Bandar & 281 & 69.6 \\
Luar bandar & 123 & 30.4 \\
\hline
\end{tabular}

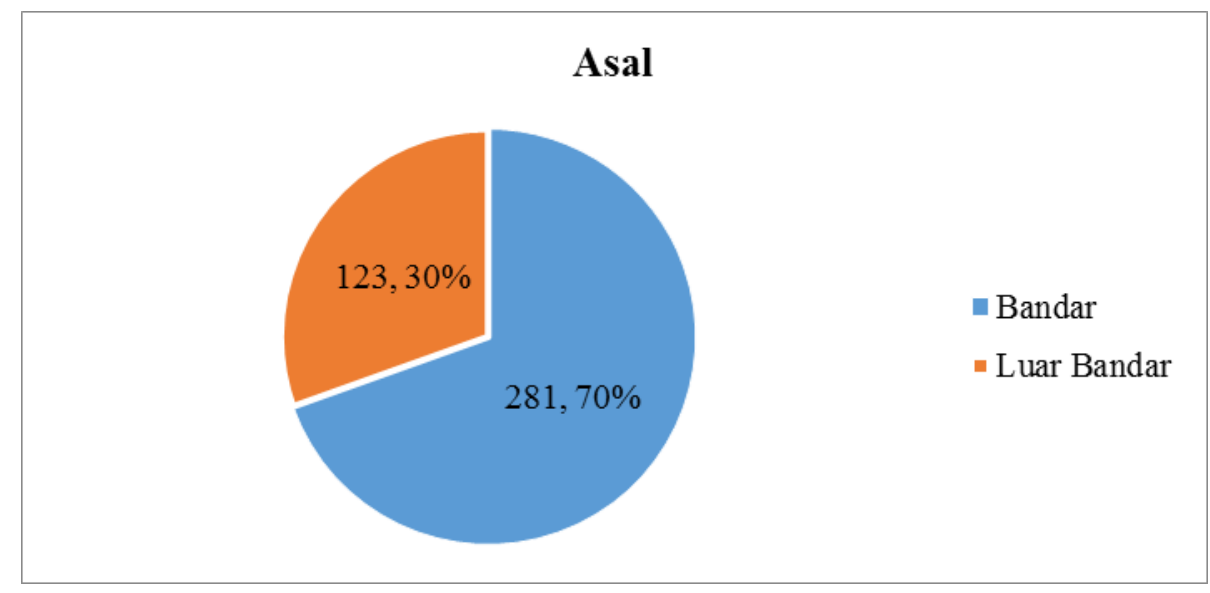

Rajah 5. Carta bar tempat asal responden 
Published by Faculty of Islamic Civilization Studies, KUIS

5. Peringkat Pengajian

Jadual 6. Peringkat pengajian responden

\begin{tabular}{llllll}
\hline Maklumat & & Kekerapan & Peratus & $\begin{array}{l}\text { Kekerapan } \\
\text { Keseluruhan }\end{array}$ & $\begin{array}{l}\text { Peratus } \\
\text { Keseluruhan }\end{array}$ \\
\hline \multirow{3}{*}{ Prasiswazah } & Sarjana Muda & 261 & 64.3 & & \\
& Diploma & 66 & 16.3 & 338 & 83.3 \\
& Asasi & 11 & 2.7 & & \\
\multirow{2}{*}{ Pasca Siswazah } & PHD & 7 & 1.7 & 51 & 12.5 \\
& Sarjana/Master & 44 & 10.8 & & 3.7 \\
\hline \multirow{2}{*}{ Lain-lain } & Program & 15 & 3.7 & 15 & \\
\hline
\end{tabular}

\section{Peringkat Pengajian}

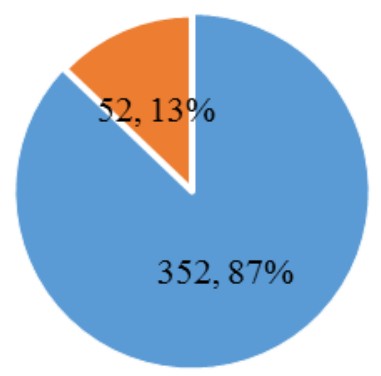

- Prasiswazah

- Pasca Siswazah

Rajah 6. Carta bar peringkat pengajian

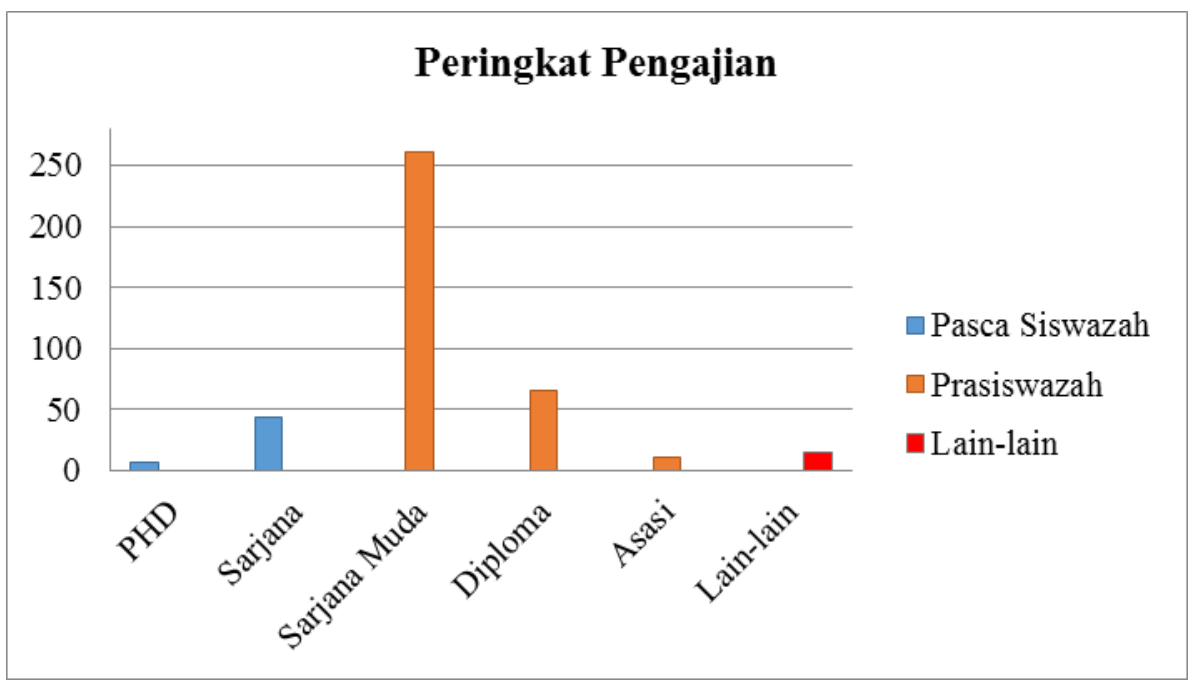

Rajah 7. Graf peringkat pengajian 
6.

Bidang Pengajian

Jadual 7. Bidang pengajian responden

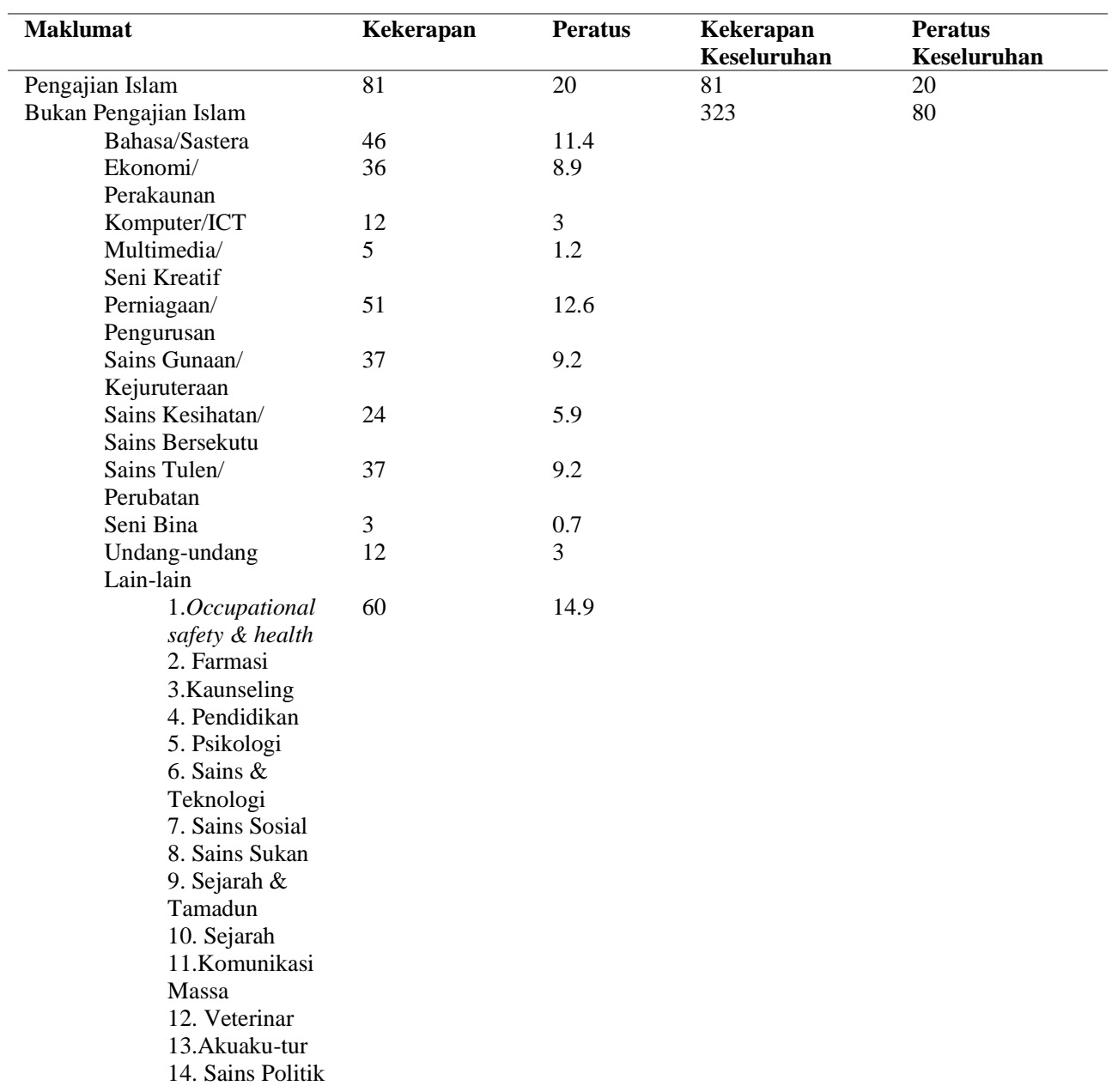




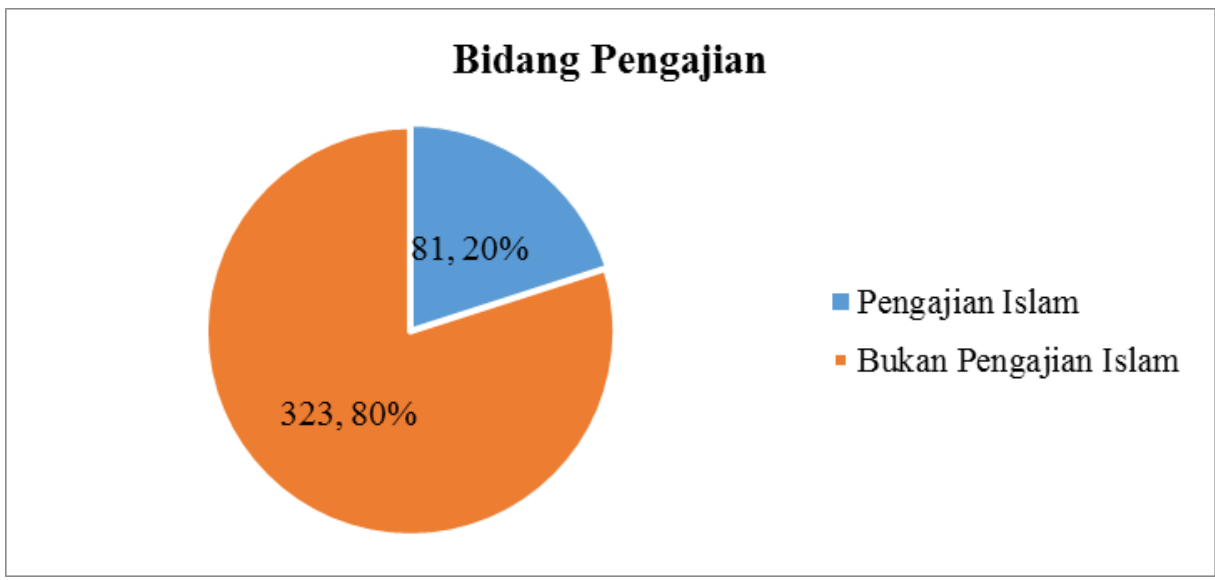

Rajah 8. Carta bar bidang pengajian

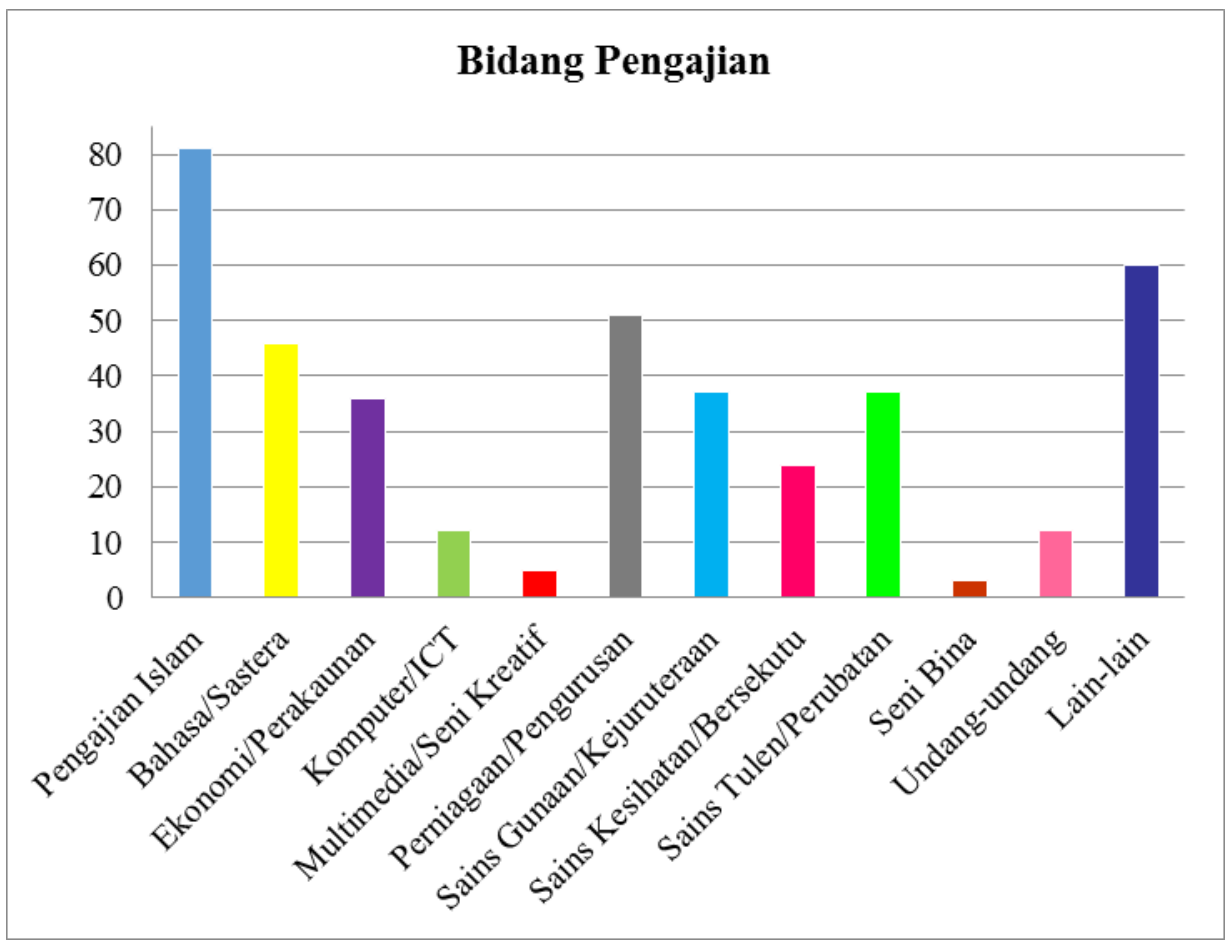

Rajah 9. Graf setiap bidang pengajian

7. Sekolah Menengah

Jadual 8. Aliran sekolah responden

\begin{tabular}{lll}
\hline Maklumat & Kekerapan & Peratus \\
\hline Sekolah Aliran Agama & 189 & 46.8 \\
Sekolah Aliran Biasa & 215 & 53.2 \\
\hline
\end{tabular}




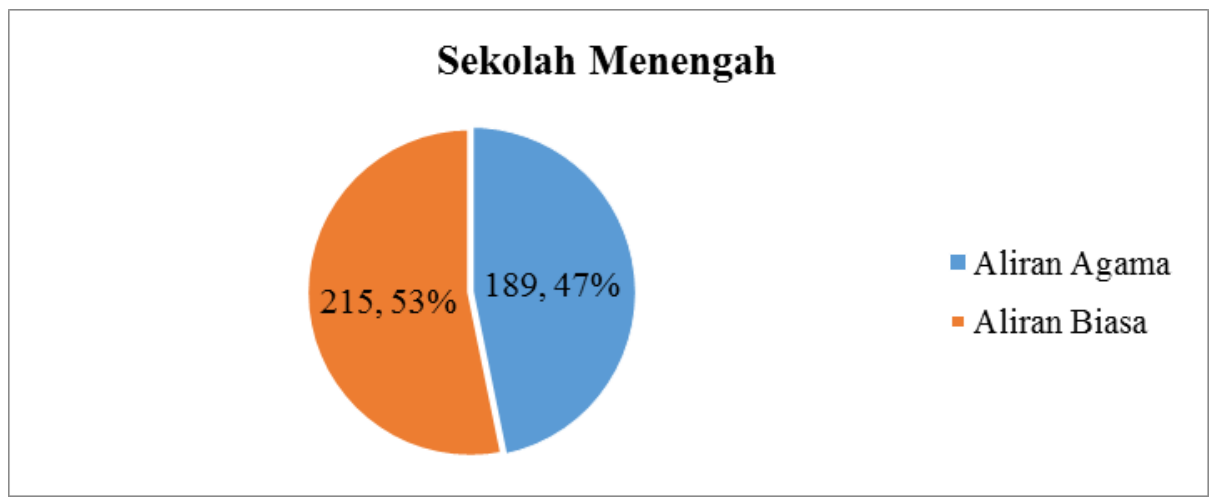

Rajah 10. Carta bar aliran persekolahan responden

8. Sektor Pekerjaan

Jadual 9. Sektor pekerjaan responden

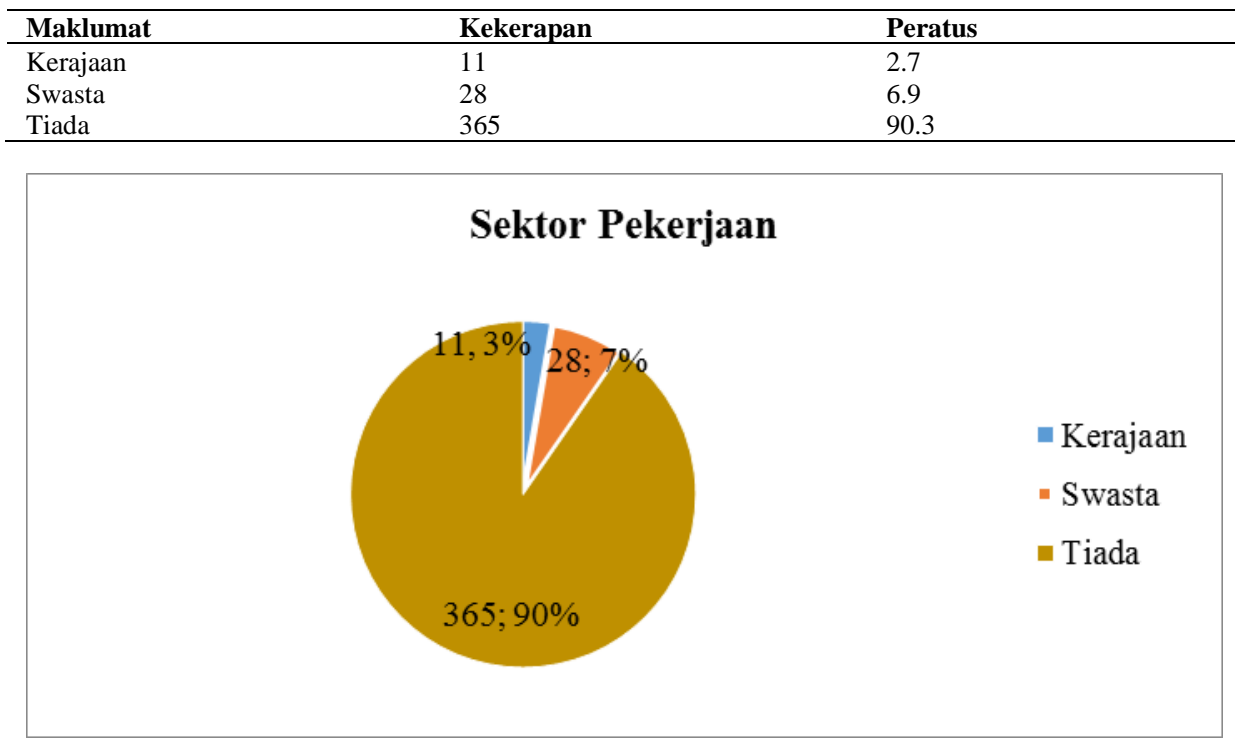

Rajah 11. Carta bar sektor pekerjaan responden

9. Penglibatan Organisasi

Jadual 10. Penglibatan organisasi responden

\begin{tabular}{lllc}
\hline Maklumat & Antaranya & Kekerapan & Peratus \\
\hline \multirow{5}{*}{ Kerajaan } & 1. JKKKK & & \\
& 2. JPJ & 7 & 1.7 \\
& 3. APM & & \\
Swasta & 4. IM4U & & \\
& 5. Umno & 49 & 12.1
\end{tabular}


Published by Faculty of Islamic Civilization Studies, KUIS

\author{
3. Belia 4B \\ 4. Mycorps \\ 5. Pembina \\ 6. Kelab Rakan Siswa \\ 7. Pepias \\ 8. Syiria Care Volunteer Club (T) \\ 9. Aqsa Syarif Tawau \\ 10. ABIM \\ 11. DKFIM \\ 12. FCR \\ 13. IITC \\ 14. Perkim \\ 15. Prudential BSN Takaful \\ 16. Ikram \\ 17. Sahabta Masjid Sri Manjung \\ 18. Gerakan Ligelasi Ganja Malaysia \\ 19. AIESEC \\ 20. Madina Institute Malaysia \\ 21. Haluan Selangor \\ 22. Agensi Nuklear Malaysia \\ 23. Hikam \\ 24. Pusat Perundingan al-Azim \\ 25. Misi Club \\ 26. Kulliyah Languanges \& Management \\ Society \\ 27. Permata \\ 28. Akademi al-Qudwah \\ 29. MccHrs \\ 30. PPMM \\ 31. MMJ \\ 32. Gamis \\ 33. Umission \\ 34. Ikatan Muslimin Malaysia \\ 35. Isma \\ 36. Alliance Francais KL \\ 37. Scout Organization \\ 38. MARDI \\ 39. Persatuan Siswa
}

\title{
Penglibatan Organisasi
}

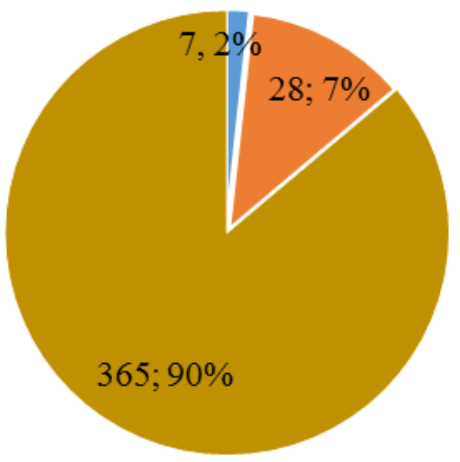

- Kerajaan

- Swasta

- Tiada

Rajah 12. Carta bar penglibatan organisasi 
10. Portal Internet

Jadual 11. Bahan bacaan portal online responden

\begin{tabular}{lll}
\hline Maklumat & Kekerapan & Peratus \\
\hline Aimnesty International & 5 & 0.7 \\
BFM Night School & 3 & 0.4 \\
Islam Lib & 29 & 3.9 \\
IRF & 26 & 3.5 \\
Malaysia Insider & 132 & 17.9 \\
Malaysia Kini & 246 & 33.4 \\
Projek Dialog & 43 & 5.8 \\
Republik Buku & 27 & 3.7 \\
Sekolah Falsafah & 25 & 3.4 \\
SUARAM & 17 & 2.3 \\
The Rational Rakyat & 24 & 3.3 \\
UTTP & 20 & 2.7 \\
Malaysia Today & 1 & 0.1 \\
Daily Mail & 2 & 0.3 \\
BBC & 1 & 0.1 \\
Lain-lain & 38 & 5.2 \\
Tiada & 98 & 13.3 \\
\hline Jumlah & 737 & 100 \\
\hline
\end{tabular}

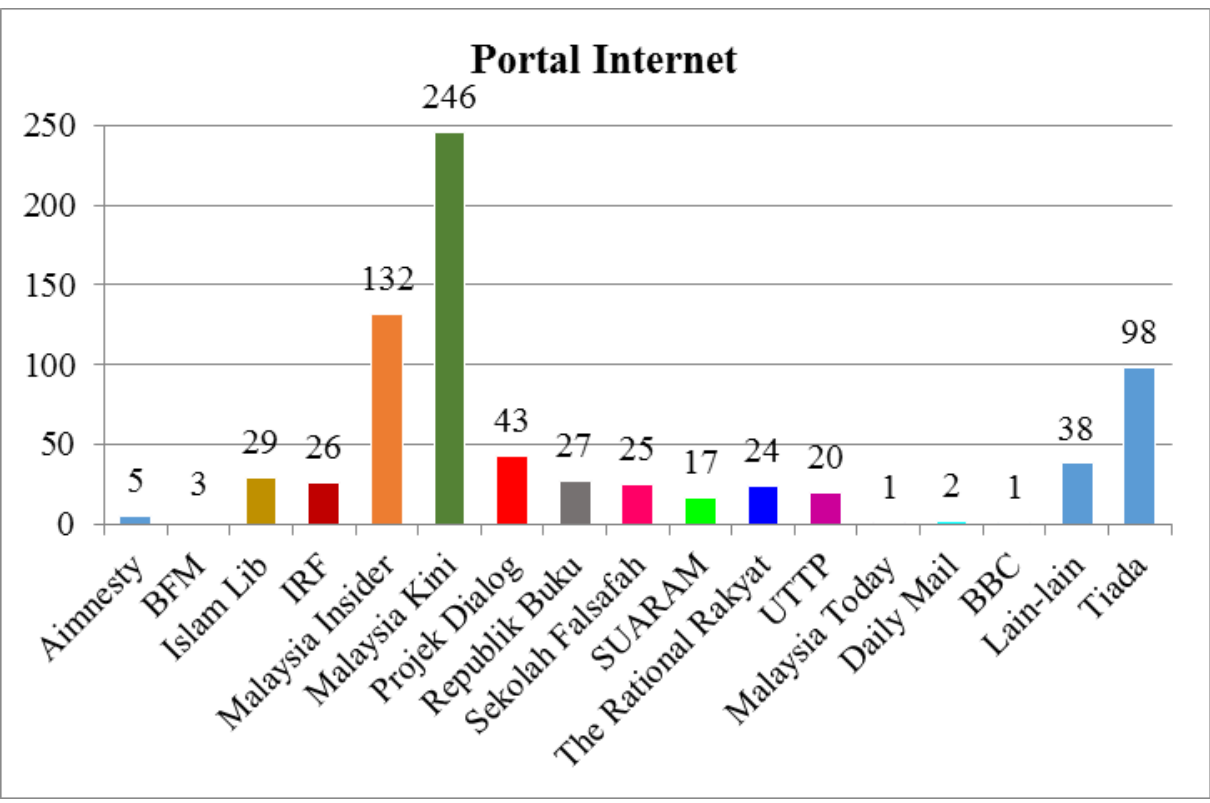

Rajah 13. Graf setiap bahan bacaan elektronik

Majoriti responden adalah mahasiswa yang sedang menuntut di IPTA dengan $59.4 \%$ (240 orang) manakala selebihnya seramai 164 orang responden bersamaan dengan $40.6 \%$ adalah mahasiswa yang sedang mengikuti pengajian mereka di IPTS. Majoriti mahasiswa IPTA ada mereka yang sedang menuntut di UKM iaitu seramai 55 orang $(13.5 \%)$ manakala majoriti mahasiswa IPTS adalah mahasiswa daripada KUIS dengan peratusan $10 \%$ (42 orang). Kekerapan responden atau mahasiswa yang paling rendah adalah mahsiswa UNITEN dengan peratusan sebanyak $1 \%$ iaitu seramai 4 
Published by Faculty of Islamic Civilization Studies, KUIS

orang responden sahaja. Seramai 218 orang (54\%) responden adalah perempuan manakala selebihnya adalah lelaki iaitu seramai 186 orang (46\%).

Umur majoriti responden pula ialah antara 18-25 tahun iaitu seramai 383 orang $(94.8 \%)$ manakala 21 orang $(5.2 \%)$ yang lain adalah mereka yang berumur antara 26-40 tahun. Oleh kerana itu, majoriti daripada responden adalah mereka yang sedang menuntut dan mengikuti pengajian peringkat prasiswazah iaitu seramai 338 $(83.3 \%)$. Majoriti daripada mahasiswa prasiswazah adalah mereka yang mengikuti pengajian sarjana muda iaitu sereamai 261 orang $(64.3 \%)$ dan yang paling sedikit bagi peringkat bagi pengajian keseluruhan responden ialah mahsiswa di peringkat PHD dengan bilangan 7 orang bersmaaan dengan $1.7 \%$. Kebanyakkan responden berasal daripada kawasan bandar, iaitu seramai 281 orang (69.6\%) dan $123(30.4 \%)$ adalah mereka yang tinggal di luar bandar. Majoriti responden adalah mahasiswa yang sedang mengikuti pengajian dalam bidang bukan Pengajian Islam, seramai 323 orang (80\%). Dalam keseluruhan kursus tersebut, seramai 51 (12.6\%) mengambil jurusan perniagaan / pengurusan dan 46 (11.4\%) mengambil jurusan bahasa / sastera. Responden yang mengikuti Pengajian Islam pula seramai 81 orang (20\%) dan selebihnya pula mengambil bidang lain-lain seperti farmasi, sains dan teknologi dan sains sukan iaitu seramai 60 orang $(14.9 \%)$. Bilangan responden yang pernah bersekolah di sekolah aliran agama adalah seramai 189 orang (46.8\%) dan sekolah aliran biasa pula seramai $215(53.2 \%)$. Oleh itu, walaupun peratusan yang agak setara antara responden sekolah agama dan sekolah aliran biasa, responden yang mempunyai latar belakang sekolah agama meneruskan pengajian mereka dalam bidang bukan Pengajian Islam di peringkat tinggi. Bersesuaian dengan peringkat pengajian prasiswazah, majoriti responden tidak bekerja dengan peratusan 90.3\% (365 orang). Selebihnya $2.7 \%$ bekerja di sektor kerajaan dan $6.9 \%$ di sektor swasta. Majoriti mahasiswa juga tidak terlibat dengan mana-mana organisasi sama ada kerajaan atau swasta (bukan kerajaan) dengan peratusan $86.1 \%$ (348 orang). 12\% (49 orang) terlibat dengan kegiatan organisasi swasta dan $1.7 \%$ pula terlibat denagn organisasi kerajaan. Majoriti mahasiswa membaca bahan bacaan yang terbuka daripada portal online seperti Malaysia Kini dengan peratusan 33.4\% (246 orang) dan Malaysia Insider $17.9 \%$ (132 orang). Manakala sebanyak $13.3 \%$ (98 orang) tidak membaca portal online yang terbuka yang telah disenaraikan.

\subsection{Tahap Kefahaman Mahasiswa Muslim Tentang Konsep Hak Kebebasan Beragama}

Bagi mendapatkan tahap kefahaman mahasiswa tentang konsep hak kebebasan beragama, set soalselidik telah menyediakan tujuh item yang berkaitan dengan definisi hak kebebasan beragama dalam Islam dan Perlembagaan Negara. Hasil kajian mendapati bahawa tahap kefahaman mahasiswa Muslim tentang konsep hak kebebasan beragama adalah tinggi dengan jumlah min keseluruhan sebanyak 4.32 (sp $=0.82$ ) seperti mana yang terdapat di dalam jadual di bawah. 
Jadual 12. Tahap kefahaman mahasiswa Muslim tentang hak kebebasan beragama

\begin{tabular}{|c|c|c|c|c|c|c|c|c|c|c|c|c|c|c|}
\hline Bil. & Item & \multicolumn{2}{|c|}{ STS } & \multicolumn{2}{|c|}{ TS } & \multicolumn{2}{|c|}{ TP } & \multicolumn{2}{|l|}{$\mathbf{S}$} & SS & $\begin{array}{c}\text { Min } \\
\%\end{array}$ & \multicolumn{2}{|c|}{ SP } & Tahap \\
\hline 2 & $\begin{array}{l}\text { Perlembagaan } \\
\text { Negara } \\
\text { menjamin hak } \\
\text { kebebasan } \\
\text { beragama. }\end{array}$ & 7 & 1.7 & 15 & 3.7 & 50 & 12.4 & 166 & 41.1 & 166 & 41.1 & 4.16 & 0.90 & Tinggi \\
\hline 3. & $\begin{array}{l}\text { Tiada paksaan } \\
\text { penganut } \\
\text { agama lain } \\
\text { untuk memeluk } \\
\text { agama Islam. }\end{array}$ & - & - & 3 & 0.7 & 8 & 2 & 84 & 20.8 & 309 & 76.5 & 4.73 & 0.53 & Tinggi \\
\hline 4. & $\begin{array}{l}\text { Agama-agama } \\
\text { lain boleh } \\
\text { diamalkan } \\
\text { dengan aman } \\
\text { dan damai. }\end{array}$ & 4 & 1 & 3 & 0.7 & 23 & 5.7 & 113 & 28 & 261 & 64.6 & 4.54 & 0.73 & Tinggi \\
\hline 5. & $\begin{array}{l}\text { Setiap individu } \\
\text { berhak } \\
\text { menganuti dan } \\
\text { mengamalkan } \\
\text { agamanya. }\end{array}$ & 3 & 0.7 & 5 & 1.3 & 17 & 4.2 & 120 & 29.7 & 259 & 64.1 & 4.55 & 0.70 & Tinggi \\
\hline 6. & $\begin{array}{l}\text { Setiap individu } \\
\text { diberikan } \\
\text { kebebasan } \\
\text { menukar agama } \\
\text { secara terbuka. }\end{array}$ & 104 & 25.7 & 96 & 23.8 & 107 & 26.5 & 58 & 14.4 & 39 & 9.7 & 3.42 & 1.28 & Sederhana \\
\hline . & $\begin{array}{l}\text { Penyebaran } \\
\text { mana-mana } \\
\text { agama tidak } \\
\text { sepatutnya } \\
\text { menggugat } \\
\text { ketenteraman } \\
\text { awam dan } \\
\text { prinsip moral. }\end{array}$ & 8 & 2 & 20 & 5 & 42 & 10.4 & 146 & 36.1 & 188 & 46.5 & 4.20 & 0.95 & Tinggi \\
\hline
\end{tabular}

Berdasarkan kepada analisis item-item dalam soal-selidik, tahap mahsiswa Islam di Lembah Klang adalah tinggi tentang maksud hak kebebasan beragama. Item ketiga iaitu 'Tiada paksaan penganut agama lain untuk memeluk agama Islam' mencatat nilai min tertinggi dengan $4.73(\mathrm{sp}=0.53)$. Hanya terdapat 3 orang $(0.7 \%)$ responden yang tidak bersetuju dengan kenyataan tiada paksaan penganut agama lain untuk memeluk Islam. Catatan min yang tinggi ini juga menunjukkan bahawa mahasiswa Muslim memahami maksud hak kebebasan beragama dalam Islam dan menepati dalil Quran (al-Baqarah ayat 256). Pemahaman ini juga dilihat konsisten apabila nilai min yang tinggi dicatatkan pada item pertama mengenai 'Setiap individu diberikan kebebasan untuk memeluk agama Islam' iaitu sebanyak 4.69 ( $\mathrm{sp=0.67).}$ Seramai 311 orang $(77 \%)$ responden sangat bersetuju dengan kenyataan ini manakala hanya 10 orang $(2.4 \%)$ tidak bersetuju. Item yang kelima 'Setiap individu berhak menganuti dan mengamalkan agamanya' pula mencatatkan min ketiga tertinggi dengan min $4.55(\mathrm{sp}=0.70)$. Hal ini menunjukkan bahawa mahasiswa memahami bahawa setiap warganegara Malaysia termasuk mereka yang tidak beragama Islam mempuyai hak untuk menganuti dan mengamalkan agama mereka. Item yang keempat 'Agama-agama lain boleh diamalkan dengan aman dan damai' mencatatkan nilai min sebanyak $4.54(\mathrm{sp}=0.73)$. Oleh yang demikian, catatan min yang tinggi pada item 1, 3, 4 dan 5 menunjukkan bahawa mahsiswa Islam di Lembah Klang memahami tentang hak kebebasan beragama terutamanya yang berkaitan dengan tiada paksaan dalam Islam dan setiap agama bebas untuk diamalkan. Item ketujuh, 'Penyebaran manamana agama tidak sepatutnya menggugat ketenteraman awam dan prinsip moral' 
Published by Faculty of Islamic Civilization Studies, KUIS

mencatatkan nilai min sebanyak $4.20(\mathrm{sp}=0.95)$. Ia menunjukkan bahawa mahasiswa memahami perlunya kawalan terhadap penyebaran agama kerana ketenteraman awam dan prinsip moral serta kesejahteraan masyarakat adalah diutamakan. Item kedua mengenai 'Perlembagaan Negara menjamin hak kebebasan beragama' mencatat nilai min sebanyak $4.16(\mathrm{sp}=0.90)$. Ia menunjukkan bahawa mahasisawa memahami tentang jaminan hak kebebasan beragama yang diperuntukan oleh perlembagaan persekutuan. Namun demikian, terdapat $5.4 \%$ (22 orang) daripada responden tidak bersetuju dengan item tersebut; menunjukkan bahawa mereka tidak meyakini terdapatnya jaminan hak kebebasan daripada perlembagaan persekutuan.

Dalam keseluruhan tujuh item yang terkandung di dalam instrumen, terdapat satu item sahaja iaitu item yang keenam mengenai 'Setiap individu diberikan kebebasan menukar agama secara terbuka' telah mencatatkan bacaan nilai min yang sederhana dengan nilai $3.42(\mathrm{sp}=1.28)$. Berdasarkan kepada jadual di atas, majoriti respoden tidak pasti dengan kenyataan tersebut dengan bilangan seramai 107 orang (26.5\%). Sebanyak $24.1 \%$ (97 orang) mahasiswa bersetuju dengan kenyataan tersebut menunjukkan mereka bersetuju dengan hak kebebasan beragama yang terbuka kepada semua individu tanpa mengira agama. Hal ini bertentangan dengan apa yang difahami melalui perlembagaan dan ajaran Islam kerana hak kebebasan adalah terbatas terutamanya kepada penganut agama Islam. Walau bagaimanapun, hampir separuh daripada responden, $49.5 \%$ bersamaan dengan 200 orang responden (sangat tidak setuju sebanyak $25.7 \%$ dan tidak setuju sebanyak 23.8\%) tidak bersetuju dengan kenyataan tersebut. Bacaan min yang sederhana pada item ini juga menunjukkan bahawa mahasiswa kemungkinan dipengaruhi oleh pembacaan dan maklumat yang diperolehi daripada media masa yang tidak ditapis mengenai isu murtad. Apatah lagi, hak kebebasan menukar agama atau murtad merupakan salah satu isu yang kontroversi dan sentiasa dipolemikkan.

\section{Perbincangan}

Kajian mendapati tahap kefahaman mahasiswa Muslim tentang konsep hak kebebasan beragama adalah tinggi $(\min =4.32, \mathrm{sp}=0.82)$. Walaupun terdapat pelbagai isu hak kebebasan beragama di Malaysia seperti isu murtad dan penyebaran ajaran bukan Islam (Nazneen Ismail et al. 2016) serta kelahiran pelbagai bentuk wacana yang mentafsirkan hak kebebasan beragama di portal online dan media masa, mahasiswa Muslim tidak terpengaruh dengan agenda yang mempromosikan maksud hak kebebasan beragama yang terbuka. Dapatan ini juga disokong oleh kajian Kamal Azmi Abd Rahman et al. (2017) yang mendapati bahawa tahap pemahaman belia tentang hak kebebasan beragama adalah tinggi dengan nilai min 3.83. Nazneen Ismail et. al. (2017) melalui kajiannya di IPTA dan IPTS Selangor juga mendapati bahawa kefahaman belia Muslim tentang konsep kebebasan beragama adalah tinggi dan kefahaman mereka tentang isu keluar agama juga tinggi. Walaupun begitu, Faisal Ahmad Shah (2015) dalam kajiannya di Wilayah Persekutuan sebaliknya mendapati bahawa tahap kefahaman masyarakat Islam tentang kebebasan beragama adalah rendah. Perbezaan dapatan kajian antara kajian di mahasiswa Muslim di Lembah Klang dengan kajian yang telah dijalankan tersebut adalah disebabkan oleh perbezaan demografi dan kaedah persampelan. Dalam kajian yang dijalankan oleh pengkaji, responden terdiri daripada golongan mahasiswa manakala kajian di Wilayah Persekutuan memilih responden yang lebih terbuka.

Namun begitu kajian lanjutan tentang kefahaman hak kebebasan beragama di Malaysia sangat diperlukan pada masa akan hadapan dengan mengambil sampel yang 
lebih besar di Malaysia. Kajian-kajian ini bertujuan untuk mengenalpasti dan menganalsis tahap kefahaman masyarakat Malaysia khususnya mahasiswa tentang hak kebebasan beragama. Dapatan kajian dapat memberikan maklumat penting bagi memastikan semua masyarakat mendapat kefahaman yang tepat tentang hak kebebasan beragama. Selain itu, masih terdapat ruang untuk penambahbaikan bagi memperbaiki tahap kefahaman mahasiswa tentang hak kebebasan beragama. Ini kerana isu hak kebebasan beragama di Malaysia turut melibatkan beberapa sub tema lain yang penting seperti murtad, penyebaran agama bukan Islam, penyebaran ajaran bukan ahli sunnah wal jamaah dan penguatkuasaan undang-undang syariah (Kamal Azmi et al. 2017). Dapatan kajian telah menunjukkan bahawa isu menukar agama pada item ke 6, 'Setiap individu diberikan kebebasan menukar agama secara terbuka' mendapat nilai min sederhana (3.42). Faisal Ahmad Shah (2015) turut menyatakan bahawa terdapat kekeliruan di kalangan masyarakat dalam memahami hak menukar agama bagi setiap individu. Kajian yang dijalankan oleh Nazneen Ismail (2017) turut menyatakan bahawa kefahaman tentang hak kebebasan beragama mempunyai hubungan dengan kefahaman mereka tentang isu murtad atau keluar agama. Oleh itu, isu murtad atau hak menukar agama merupakan isu penting dalam perbincangan hak kebebasan beragama yang perlu diberikan perhatian bagi kajian-kajian akan datang.

\section{Kesimpulan}

Secara keseluruhannya, kajian telah mendapati bahawa tahap kefahaman mahasiswa Muslim tentang konsep hak kebebasan beragama adalah tinggi $(\min =4.32, \mathrm{sp}=0.82$ ). Ia menunjukkan bahawa mahasiswa Muslim tidak dipengaruhi oleh agenda yang mempromosikan maksud hak kebebasan beragama yang terbuka oleh beberapa NGO seperti IFC dan COMANGO di portal-portal online dan media masa. Walaupun begitu, beberapa bahagian dalam hak kebebasan beragama perlu diberikan perhatian kerana terdapatnya kekeliruan dalam kalangan mahasiswa. Antara perkara yang perlu diberikan perhatian ialah mengenai hak menukar agama ataupun murtad yang seringkali menjadi isu sentral dalam perbincangan hak kebebasan beragama. Oleh itu, institusi pengajian tinggi perlu mengambil langkah proaktif untuk menjelaskan isu tentang hak kebebasan beragama, silang agama, kedudukan agama Islam dan agama lain dalam perlembagaan serta aspek-aspek lain berkaitan perundangan negara kepada golongan mahasiswa. Penjelasan ini bertujuan untuk memastikan supaya golongan mahasiswa terutamanya mahasiswa Muslim mendapat kefahaman yang tepat mengenai hak kebebasan beragama yang didiasari oleh kerangka Islam dan Perlembagaan Negara. Kefahaman tentang hak dan tanggungjawab dalam hal-hal yang berkaitan dengan kebebasan beragama akan menghasilkan kehidupan yang harmoni dan saling hormat-menghormati dalam masyarakat. Ia dapat mengurangkan ketegangan dalam pengamalan cara hidup beragama di Malaysia yang berlatarbelakangkan kehidupan kepelbagaian agama, bangsa dan tradisi.

\section{Penghargaan}

Kolej Universiti Islam Antarabangsa Selangor (KUIS), Geran Penyelidikan dan Inovasi Kuis (GPIK). No geran KUIS/PB/2016/GPIK1/GPM/015. 


\section{Published by Faculty of Islamic Civilization Studies, KUIS}

\section{Rujukan}

Abdul Monir Yaacob. (1986). Hak Asasi Manusia Menurut Islam. Bangi: Universiti Kebangsaan Malaysia.

Ahmad Munawar Ismail dan Mohd Nor Shahizan Ali. (2016). Mengenali Kuantitatif dan Kualitatif dalam Penyelidikan Pengajian Islam. Bangi: Universiti Kebangsaan Malaysia.

Andrey Sujatmoko. (2009). Sejarah, Teori, Prinsip dan Kontroversi HAM. PUSHAM UII Yogyakarta dengan bekerjasama dengan Norwegian Centre for Human Rights (NCHR) Universitas Oslo-Norwegia, dalam pembentangan Training Metode Pendekatan Pengajaran, Penelitian, Penulisan Disertasi dan Pencarian Bahan Hukum HAM, Hotel Santika Premiere, Yogyakarta. 12-13 Mac 2009: 1-20.

Che Bakar Che Mat. (t.th.). Hak Asasi Manusia Dalam Sistem Nilai Pasca Modenism. Cawangan Sarawak, Kampus Samarahan. Universiti Teknologi MARA.

Faisal Ahmad Shah. (2015). Kebebasan Beragama: Analisis Tahap Kefahaman Masyarakat Islam di Wilayah Persekutuan Kuala Lumpur. Jurnal Pengajian Islam, 8(1): 76-98.

Faridah Jalil \& Rohizan Halim. (2014). Kebebasan Beragama: Gambaran Malaysia. Kanun, 6, 220-235.

Frans Sayogie. (2013). Perlindungan Negara Terhadap Hak Kebebasan Beragama: Perspektif Islam dan Hak Asasi Manusia Universal. Jurnal Hukum PRIORIS, 3(3).

Ghazali Darusalam dan Sufean Hussin. (2016). Metodologi Penyelidikan dalam Pendidikan. Kuala Lumpur: Penerbit Universiti Malaya.

Helwa Mohammad dan Zainal Jasri Jamal. (2013). Kedudukan Murtad dan Penyebaran Agama Bukan Islam Menurut Perspektif Undang-Undang di Malaysia: Satu Analisa Isu dan Cabaran. Jurnal Undang-undang \& Masyarakat 17:13-36.

Ismail, N., Abdul Rahman, K. A., \& Mohd Salleh, N. (2017). Kefahaman belia Muslim terhadap konsep kebebasan beragama dengan isu keluar agama dalam Islam: kajian di Institut Pengajian Tinggi Selangor. Al-Irsyad: Journal of Islamic and Contemporary Issues, 2(2), 54-67. https://doi.org/10.53840/alirsyad.v2i2.18.

Ismail Raji al-Faruqi. (2009). Islam dan Kepercayaan Lain. Ataullah Siddiqui (Terj.). Wangsa Maju: Institut Terjemahan Negara Malaysia Berhad.

Jaafar Salleh. (2010). Islam Melindungi Hak-hak Asasi Manusia Sejagat. Petaling Jaya: Mulia Terang Sdn Bhd.

Jabatan Agama Islam Selangor (JAIS). (2004). Liberalisme dan Pluralisme Agama: Hakikat dan Impak. Selangor: Bahagian Penyelidikan dan Pembangunan Jabatan Agama Islam Selangor.

Kamal Azmi Abd. Rahman. 2017. Kajian Awal Tentang Tahap Kefahaman Belia Islam Di Lembah Klang Tentang Hak Kebebasan Beragama. e-Jurnal Penyelidikan Dan Inovasi, 4(2), 173-201.

Mafis Mohd Samuri. (2012). Penghakisan Nilai Agama Melalui Doktrin Hak Asasi Manusia. Panel Jawatankuasa Pemikir Isu Islam Semasa Pejabat Mufti Wilayah Persekutuan: 1-12.

Majda El Muhtaj. (2008). Dimensi-Dimensi HAM: Mengurai Hak Ekonomi, Sosial dan Budaya. Jakarta: PT. Raja Grafindo Persada. 
Md Akhir Hj. Yaacob. (1986). Hak Asasi Manusia Menurut Islam; Satu Pendekatan Perbandingan. Bangi: Dewan Pustaka Fajar.

Mohd Nur Hidayat Hasbollah Bin Hajimin. (2012). Hak-hak Non-Muslim dalam Pentadbiran Negara Menurut al-Mawardi. Bangi: Universiti Kebangsaan Malaysia.

Nazneen Ismail, Nurulfathonah Mohd Effendy, Kamal Azmi Abd. Rahman, Norsaleha Mohd. Salleh \& Indriaty Ismail. (2017). Isu-Isu Hak Kebebasan Beragama di Malaysia. Prosiding International Conference On Law \& Islamic Jurisprudence (ICLIJ 2017).

Nik Safiah Nik Abdullah, Selamah Maamor dan Norazlina Abd Wahab. (t.th.). Pengurusan Pembangunan Belia Dari Perspektif Islam. Universiti Utara Malaysia, Sintok, Kedah: 17-25.

Retno Kusniati. (2011). Sejarah Perlindungan Hak-Hak Asasi Manusia dalam Kaitannya dengan Konsepsi Negara Hukum. Dlm. Bimbingan Teknik, HAM Pejabat Wilayah Kementerian Hukum dan HAM. Jambi. 24 Mei 2011: 79-92.

Ridwan Arif. (2010). Kebebasan Awam (Civil Liberty) Menurut Jaringan Islam Liberal (JIL) di Indonesia. Bangi: Universiti Kebangsaan Malaysia.

Salman Zainal Abidin, Jaffary Awang, Zulkefli Aini, Wan Haslan Khairuddin, Kamal Azmi Abd. Rahman, Abu Zaki Ismail, Muhammad Yusuf Marlon Abdullah, Maryam Habibah Kamis dan Nurfida'iy Salahuddin. (2014). Kajian Tahap Kefahaman Akidah Belia Islam Berisiko Tinggi Di Selangor. Bahagian Pemulihan al-Riqab. Majlis Agama Islam Selangor.

Siti Musdah Mulia. (2006). Menuju Kebebasan Beragama di Indonesia. Dlm. Kebebasan Beragama atau Kepercayaan di Indonesia. Komisi Nasional Hak Asasi Manusia: 39-60.

\section{Author's Biography}

Kamal Azmi Abd. Rahman, graduan lulusan Universiti Islam Antarabangsa Malaysia (UIAM) di peringkat ijazah sarjana dalam bidang Ilmu Wahyu (Usuluddin). Kini, beliau sedang melanjutkan pengajian di peringkat $\mathrm{PhD}$ di Universiti Kebangsaan Malaysia (UKM) di dalam bidang falsafah dan pemikiran. Beliau juga sedang berkhidmat di Jabatan Usuluddin, Kolej Universiti Islam Antarabangsa Selangor (KUIS). Penulisan-penulisan beliau banyak tertumpu kepada bidang falsafah dan pemikiran Islam. Beliau boleh dihubungi melalui emel: kamalazmi@kuis.edu.my. 